\title{
Can probiotics win the battle against environmental endocrine disruptors?
}

\author{
Çiğdem Sevim ${ }^{1 *}$, Mehtap Kara ${ }^{2}$ \\ ${ }^{1}$ University of Kastamonu - Faculty of Medicine, Deparment of Medical Pharmacology, \\ 37200, Kastamonu, Turkey \\ ${ }^{2}$ University of Istanbul - Faculty of Pharmacy, Deparment of Pharmaceutical \\ Toxicology, 34116, Istanbul, Turkey
}

*Corresponding author: Çiğdem Sevim, e-mail: cigdemsevim@kastamonu.edu.tr

\begin{abstract}
Compounds that have negative effects on the endocrine system are called endocrinedisrupting compounds (EDCs). There are several different types of compounds, with several different usage areas in the environment, which can be classified as EDCs. These chemicals have a wide range of negative health effects in organisms, depending on their target hormone system. EDCs are among the most popular topics of scientific research, as they are widely used and organisms are frequently exposed to these chemicals. There are various exposure routes for EDCs, such as oral, inhalation and dermal exposure. Parabens, phenolic compounds, phthalates, and pesticides are the most common EDCs. Nowadays, intestinal microorganism distribution, probiotics, and food supplements that regulate these microorganisms and their protective effects against various harmful chemicals attract attention. For this reason, many studies have been carried out in this field and certain diet schemes have been created according to the results of these studies. In fact, probiotics are preferred in order to reduce and eliminate the negative effects of harmful chemicals and to ensure that the organism reacts strongly in these conditions. In this review, we will focus on EDCs, their health effects and positive effects of probiotics on EDCs exposure conditions.
\end{abstract}

Keywords: Endocrine-disrupting compounds, pesticides, phthalates, probiotics

doi.org/10.5937/arhfarm71-34237 


\section{Introduction}

The compounds that disrupt the structure and functioning of the endocrine system elements in organisms or have negative effects on the structures that are the target of hormones are called endocrine-disrupting compounds (EDCs). EDCs influence many stages of hormones, such as synthesis, secretion, transport to target, binding with target molecule, signaling at target. Therefore, they have a negative effect on many systems. These effects can be summarized as immune system activation or suppression, impaired thyroid secretion, reproductive functions in both genders, deterioration of secondary sex characteristics, and cancer [1]. Pesticides and phthalates are the most common endocrine disruptors in nature $[2,3]$. They show their effects in various ways after they enter the body by oral, inhalation or dermal route. Most commonly, they bind to the target surface or intracellular receptor by mimicking the hormone structure and activate or inactivate cellular signaling pathways $[4,5]$. They can also impact on the signaling mechanism that is activated after binding to the hormone receptor in various ways $[6,7]$ and disrupt the production process of hormones.

In recent years, the health effects of various food supplements and the prevention of adverse health effects that may occur due to exposure to various chemicals in industrialized societies, and even their therapeutic properties in health deterioration due to exposure, have gained traction. The number of studies on the preventive or therapeutic effects of probiotics against endocrine-disrupting chemicals is increasing day by day. As is known, the intestines are the most active organ and have an important place in whole body homeostasis. In particular, changes in the intestinal flora caused by various reasons can result in serious diseases. For this reason, it is important to keep the intestinal flora in balance and to support it regularly, both for the continuity of the health of the organ and against the factors that threaten the health from the outside. There are many studies which show the positive effects of probiotics on various endocrine system elements [8-10].

One of the most important issues in microbiome research is the identification of the positive effects of various microorganisms on human health and their use for these purposes. It is known that microorganisms have many positive effects on metabolic functions, systematic functioning of cellular pathways and the immune system. It has even been reported that some microorganisms act by degrading toxins in the body [11]. Two very important functions of the bacterial flora in the gut are the regulation of the immune system and endocrine activities in the body [12]. Interestingly, some commensal bacteria could have the ability to produce hormones [13]. In the endocrinology research era, firstly, numerous studies evaluating the effects of changes in the endocrine system balance on microbiota have been conducted. In addition, studies evaluating the effects of different neurotoxins on the endocrine system have been carried out. Quorum sensing (QS) has emerged as a mechanism that can mediate the effects of bacteria on the endocrine system and the endocrine system on bacteria. This concept can be defined in simplest terms as the conversation of bacteria with its environment [14]. In many different studies, the effects of changes in the amount of hormone secretion of the host organism on bacteria have been observed $[13,15,16]$. 
There are two main probiotic groups, Lactobacillus and Bifidobacterium, while potential probiotics are Pediococcus, Lactococcus, Bacillus and yeasts. While probiotics are mainly ingested through dairy products, they can also be taken through food and food supplements other than dairy products. Each bacterial species has a different probiotic positive potential. In this case, it is important which bacterium creates which positive feature and its specific use for the target. Different probiotic formulations that could include species of bacteria are recommended for several years for immunomodulation with antibiotic usage during infections. The standards for the preparation of probiotic bacteria for therapeutic and food supplement use are regulated by the World Health Organization (WHO), European Food Safety Authority (EFSA) and Food and Drug Administration (FDA) [17, 18].

The relationship between the microorganisms in the intestinal flora and the probiotics taken as supplements with the endocrine system directly or indirectly affects the mechanisms of action of various endocrine disruptors that naturally have a negative effect on the endocrine system. In community studies conducted in India, it has been found that diabetogenic changes and glucose metabolism changes can be observed together with intestinal flora changes in case of exposure to different endocrine-disrupting compounds, or when they are detected in high amounts in the body. In different studies, it has been shown that substances such as Bisphenol A, Carbemazine, Polycyclic aromatic hydrocarbons (PAH), organophosphate pesticides and phthalates cause changes in the flora of target organisms, while also causing changes in the amounts of estrogen, cortisol, adipose tissue hormones, and reproductive system hormones (Table I) [19].

Gut microbiota could affect host behavioral conditions by affecting the release levels of dopamine, epinephrine and norepinephrine, as well as stress hormones such as cortisol, corticosterone, adrenocorticosterone and corticotropin through gut-brain axis modulation [11]. The gut-thyroid axis emerges as an important concept in endocrine system homeostasis. In autoimmune thyroid diseases, it has been shown that there are changes in the intestinal microbiota, and these changes cause changes in the absorption of minerals that mediate efficient thyroid hormone synthesis and, consequently, thyroid gland dysfunction. In addition, intestinal flora changes may lead to hyperactivation of the immune system by causing the excessive passage of some antigens, which may pave the way for autoimmune thyroid diseases [20, 21]. Talebi et al. (2019) suggested in their study that symbiotic usage could have a positive effect on thyroid hormone release and anti-inflammatory modulators in Hashimoto thyroid patients [22]. Probiotics have shown beneficial effects on endocrine system elements and are able to have a positive effect on trace elements such as selenium, zinc, and copper, which play a role in endocrine system modulation. Probiotics could constitute an adjuvant therapy for endocrine system diseases. However, most studies on probiotics rely on animal models; therefore, welldesigned human studies are needed to further elucidate the importance of the endocrine system. 
Table I Effects of probiotics on endocrine disruptor toxicity.

Tabela I Efekti probiotika na toksičnost endokrinih ometača.

\begin{tabular}{|c|c|c|c|}
\hline Chemical Group & Main effects & $\begin{array}{l}\text { Effect on gut microbiome } \\
\text { composition }\end{array}$ & \\
\hline \multirow{3}{*}{ Bisphenol A } & $\begin{array}{l}\text { Estrogenic effects on parents and } \\
\text { offspring }\end{array}$ & $\begin{array}{l}\text { Changes of microbiota in relation to } \\
\text { the female sex }\end{array}$ & [23] \\
\hline & $\begin{array}{l}\text { Classical endocrine disruptor } \\
\text { affecting both male and female } \\
\text { reproduction }\end{array}$ & $\begin{array}{l}\text { Overabundance of Protobacteria } \\
\text { similar to a high-fat diet }\end{array}$ & [24] \\
\hline & $\begin{array}{l}\text { Changes of hematological and } \\
\text { plasma parameters including } \\
\text { cortisol levels }\end{array}$ & $\begin{array}{l}\text { Negative correlation of Bacteroides } \\
\text { and Flexispiraphyla with BTA levels }\end{array}$ & [25] \\
\hline Carbemazin & $\begin{array}{l}\text { Affects male fertility by the } \\
\text { destruction of testicles }\end{array}$ & $\begin{array}{l}\text { Relative abundance of Firmicutes, } \\
\text { Protobacteria, Actinobacteria, } \\
\text { decrease of Bacteriodetes }\end{array}$ & [26] \\
\hline $\begin{array}{l}\text { Polycyclic aromatic } \\
\text { hydrocarbons (PAH) }\end{array}$ & $\begin{array}{l}\text { Endocrine signaling disruptors } \\
\text { (Peroxisome proliferator- } \\
\text { activated receptor and } \\
\text { adinocytokine signaling pathway } \\
\text { decreased with higher PAH } \\
\text { concentration) }\end{array}$ & $\begin{array}{l}\text { Altered Actinobacteria, Bacteriodes } \\
\text { and Proteobacteria communities }\end{array}$ & [27] \\
\hline $\begin{array}{l}\text { Diazinone, Triclosan } \\
\text { and their mixture }\end{array}$ & $\begin{array}{l}\text { Acetylcholinesterase inhibitor, } \\
\text { neurotoxicity }\end{array}$ & Changes of the gut microbiome & [28] \\
\hline $\begin{array}{l}\text { Diethylphtalate, } \\
\text { Methylparaben, } \\
\text { Triclosan and their } \\
\text { mixture }\end{array}$ & $\begin{array}{l}\text { Broad effects on female and male } \\
\text { reproduction }\end{array}$ & $\begin{array}{l}\text { Relative increase of Bacteriodes } \\
\text { phyla and decrease of Firmicutes }\end{array}$ & [29] \\
\hline $\begin{array}{l}\text { Pentachlorophenol } \\
\text { (PCP) }\end{array}$ & $\begin{array}{l}\text { Increase of oxidative stress, liver } \\
\text { damage and reduction of body } \\
\text { weight }\end{array}$ & $\begin{array}{l}\text { Increase of phyla Bacteriodes, } \\
\text { Bacteroidetes, decrease of } \\
\text { Fumicutes, Chrysobacterium, } \\
\text { Microbacterium,Legionella,Anthrob } \\
\text { acter }\end{array}$ & [30] \\
\hline
\end{tabular}




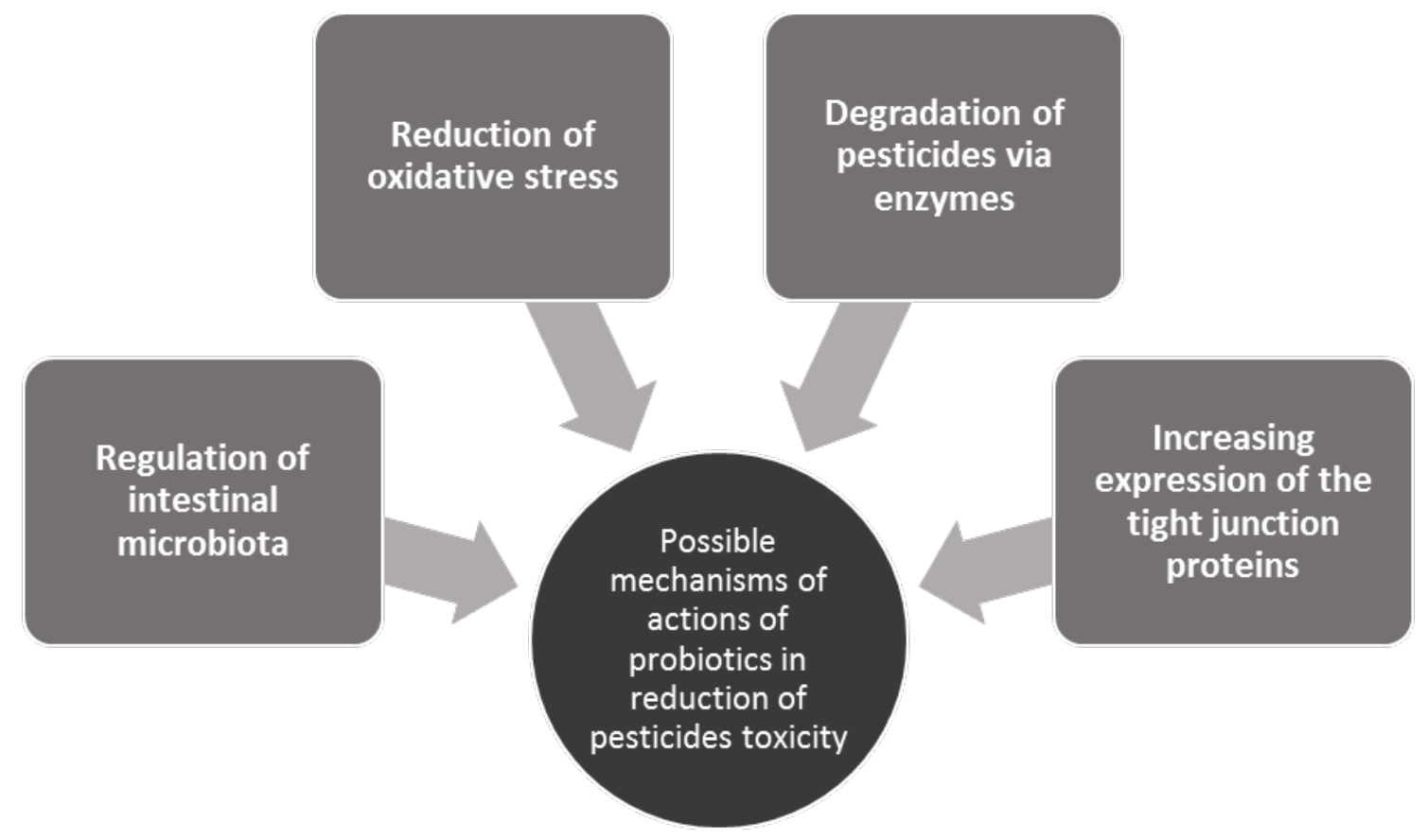

Figure 1. The relationship between probiotics and pesticide toxicity [31].

Slika 1. Odnos probiotika i toksičnosti pesticida (31).

The possible effects of probiotics on pesticide toxicity are shown in Figure 1. Probiotics have been found to include pesticide-degrading genes encoded into enzymes with degrading activities such as organophosphorus hydrolases, methyl parathion hydrolases, and organophosphorus acid anhydrases. Gene expression in these microorganisms increased in the presence of pesticides [31]. Studies have shown that pesticides can interact with gut microbiota, affecting the receptor sites of different tissues and organs, destroying the intestinal mucosa and cells that lead to pathological changes [32]. Probiotics produce antimicrobial substances that compete with other gut microbes for nutrients and binding sites. In addition, probiotics improve the integrity of the intestinal barrier and regulate intestinal immunity. The relationship between endocrinedisrupting chemicals and probiotics is explored in more detail below.

\section{Phthalates}

Phthalate acid esters have frequently been used in plastic materials in the past, and some derivatives are still used. They are also widely used as solvents with various industrial applications. Due to their widespread use, they are considered to be the most common man-made environmental pollutants. There are many chemicals classified as phthalates, and most of them have serious toxic effects on organisms. Polyvinyl chloride plastics (PVCs), are widely make flexible via using as plasticizers including cosmetics, shoe industry, toys, medical devices, etc. Several different types of phthalates have spread into the environment through these products or during their production processes [33]. 
Chronic exposure to phthalates in various ways is associated with decreased fertility, increased miscarriage, impaired ovulation, decreased sperm quality, disorders in hormonal systems and teratogenicity. Di-2-ethylhexyl phthalate (DEHP) is one of the commonly detected phthalate types in the environment. DEHP exposure could occur via oral, inhalation, dermal and intravenous exposure ways. DEHPs main toxic effect is reproductive toxicity and developmental toxicity. DEHP exerts its toxic effects by mimicking a steroid hormone and disrupting the intracellular molecular signaling system. The effects of DEHP include the decrease in testosterone levels, disruption in testicular development during the fetal period, Leydig cell steroidogenesis disruption and an increase in estrogenic activity in females. Mono-ethylhexyl phthalate (MEHP) is yet another important phthalate type. MEHP exerts its endocrine-disrupting effect primarily on the ovaries via suppressing aromatase activity. MEHP effects aromatase gene expression levels on peroxisome proliferators receptors (PPARs) activation [33-36].

DEHP has a serious disruptive effect on reproductive health. Tian et al. (2019) reported that Lactobacillus plantarum TW1-1 (L. plantarum TW1-1) improved male reproductive system functions by increasing serum testosterone hormone levels, improved the quality of semen, and ameliorated gonad development defects in DEHPexposed mice [37]. In another study, one by one and mix treatment with probiotics such as Saccharomyces boulardii, Lactobacillus rhamnosus, Lactobacillus planarum LP 6595, Lactobacillus planarum, attenuated the toxic effects of a DEHP, Di-n-butyl phthalate (DBP) and Bisphenol A mixture. Probiotic usage improved serum glucose levels and organ size changes, and reduced inflammation processes in different organs such as the

liver [38]. Nevertheless, studies on phthalate types and their effects on gut microbiota, as well as on the determination of changes in different types of phthalate toxic action mechanisms in probiotic supplementation, are very scarce in the literature. It is important to determine the effect of probiotic supplements because of involuntary exposure to phthalates and it is necessary to carry out numerous studies on this subject.

\section{Pesticides}

Pesticides are frequently used for the removal of harmful insects in agricultural lands, and $50 \%$ of the pesticides used for this purpose are Organophosphate pesticides. According to the report of the Commission of the European Communities, $45 \%$ of fruit and vegetables contain pesticide (MRL) residues at a maximum level. These pesticides get stored in various tissues of plants and become part of the food chain when the edible parts of these plants are consumed by humans. In a risk analysis study published by Tank et al. in 2021, it was found that 64\% (approximately 24.5 million $\mathrm{km}^{2}$ ) of global agricultural lands are at risk of pesticide pollution due to multiple active ingredients, and $31 \%$ are at high risk [39].

Pesticides are substances that contain insecticides, herbicides, fungicides, rodenticides, miticides, and other growth regulators. They are classified according to their chemical structures, modes of action, and toxicity levels, and they contain different organic and inorganic active substances. They are divided into 4 main categories: organophosphates, organochlorines, carbamates, and pyrethroids. 
Various studies are being conducted to identify the potential of probiotics to prophylactically inhibit the absorption of environmental toxins such as pesticides, heavy metals, and aflatoxins. Some pesticides are known to be metabolized by enzymes produced by microbiota. In particular, lactobacilli have been shown to reduce organophosphate pesticide contamination in dairy products and wheat. Although the mechanism of action remains unclear, it has been suggested that it is generally dependent on the phosphatase activity of the bacteria [40]. Chlorpyrifos, an organophosphate insecticide, is metabolized by the microbiota via biotransformation to a more toxic molecule, 3,5,6-trichloro-2-pyridinol, with more biologically adverse consequences on host health. However, some types of bacteria such as Pseudomonas spp. and L. lactis, E. coli, and L. fermentum found in the gastrointestinal tract can use 3,5,6-trichloro-2pyridinol as the sole carbon and energy source [41, 42]. Many studies have analyzed the viability, colonization ability, and capacity to bind to toxic substances of probiotics. Lactobacillus casei DN 114001 can bind to in vitro heterocyclic aromatic amines and reduce the concentration and genotoxicity of these amines [43]. Lactobacillus reuteri NRRL 14171 and Lactobacillus casei, Shirota and Bifidobacteria strains can bind to aflatoxin B1 and prevent the absorption of aflatoxins in the intestinal tract [44, 45]. Lactobacillus kefir strains were able to bind Clostridium difficile toxins with surface layer (s layer) proteins [46]. In vitro studies, studies using cell culture, and in vivo animal studies have shown that probiotics can bind to toxic substances and prevent their absorption. For example, in a study conducted to demonstrate the protective effects of probiotics, it was revealed that the absorption of aflatoxins was reduced by probiotics in a rat model with liver damage caused by ethanol [47]. Evidence has shown that Lactobacilli can alleviate acute and chronic cadmium $(\mathrm{Cd})$ toxicity, protect organisms against pesticide toxicity, reduce the risk of antibiotic-associated diarrhea (AAD), and rebalance the gut microbiota $(\mathrm{GM})[48,49]$. The intestinal flora is known to play an important role in the regulation of immunity, metabolism, as well as the bioavailability and toxicity of various pollutants. Strong evidence has shown that intestinal flora can be modified with probiotics and contribute to the detoxification of environmental pollutants. Intestinal microbiome development was affected in mice exposed to malathion [50]. The effect of Glyphosate on poultry microbiota has been proven with the increased resistance to pathogenic bacteria, including Salmonella gallinarum, Salmonella typhimurium, Clostridium perfringens, and Clostridium botulinum, and the increased susceptibility to most beneficial bacteria, such as Enterococcus faecalis, Enterococcus faecium, Bacillus badius, Bifidobacterium adolescentis, and Lactobacillus spp., which provide protection against pesticide-induced oxidative stress and cellular damage. Several studies have shown that endosulfan-induced oxidative stress and MDA concentration in the liver and kidney can be reduced with Lactobacillus plantarum BJ0021 supplementation [51]. Another study showed that Lactobacillus casei ATCC 334 could reduce DNA damage in rats exposed to the carcinogen 12-dimethylhydrazine [52]. Probiotics maintain the integrity of the intestinal barrier and reduce the absorption of pesticides. One study found that L. plantarum MB 452 increased the expression of proteins that form tight junctions 
between cells, such as occludin, ZO-1, ZO-2, and cingulin in the Caco-2 intestinal cell line [53]. Lactobacilli activate the host's own immune and detoxification mechanisms to resist pesticides and reduce pathogen invasion. It was demonstrated that the probiotic $\mathrm{L}$. plantarum ATCC 14917 stimulated immunity in fruit flies exposed to imidacloprid and reduces pathogenic microorganism (Serratia marcescens) infections [54].

In a 2016 study, it was stated that Lactobacillus bacteria could bind parathion and chlorpyrifos, but do not metabolize OP pesticides and reduce intestinal absorption in vitro. In another study, mortality and growth defects decreased in Drosophila exposed to $\mathrm{CPF}$ and pre-treated with Lactobacillus rhamnosus, while in a study with DZN, other Lactobacillus strains, such as Lactobacillus casei, were shown to reduce DZN-induced cytotoxicity $[55,56]$. However, there are studies suggesting that AChE inhibition is not the only mechanism responsible for toxicity and non-cholinergic mechanisms are responsible for it too. Cardona and López-Granero (2013) showed that acyl peptide hydrolase was more sensitive to inhibition by OPs than AChE $[57,58]$. It has been stated that agents such as diazinon trigger oxidative stress in biological systems and increase free radical production, which is a major stimulant of apoptosis in different organs [59]. In another study with male rats, it was shown that Diazinon increased lipid peroxidation and decreased antioxidant biomarkers [60].

In a study conducted with male rats, it was stated that antioxidant-effective probiotic Lactobacillus acidophilus increased antioxidant levels such as glutathione reductase, superoxide dismutase, and glutathione peroxidase, while decreasing malondialdehyde levels. In another study conducted with DZN, it was stated that the antiapoptotic effects of L. casei in HUVEC cells treated with DZN were probably due to the reduction in oxidative stress and antioxidant effects [56, 61].

\section{Food contact materials and diet}

Food products can be contaminated with contaminated raw materials or during processing, which is a major concern in food health and safety globally. Although many measures have been taken for safe food production, they have not been sufficient and the health threat still continues. This is often caused by polycyclic aromatic hydrocarbons, heterocyclic aromatic amines, and acrylamide, mycotoxins, phthalic acid esters, heavy metals, and pesticides as process-derived toxic compounds.

Using microbes to reduce pesticides is one of the most important strategies in innovative technologies with less chemical application. It is known that bacteria can break down pesticides in environmentally contaminated soil and water [62]. Studies have shown that L. plantarum, in which $81 \%$ of pirimiphos-methyl is decomposed by L. plantarum during wheat fermentation, decomposes $96.2-99.7 \%$ of chlorpyrifos, dichlorvos, phorate, and trichlorfon in Chinese cabbage pickle [63].

Aflatoxin B1 is an inevitable food contaminant. It has been stated that when probiotics are used, AFB1 binds less to the intestinal surface and decreases the absorption of AFB1, while increasing its excretion. Another study stated that there was a decrease in 
Aflatoxin M1 level in yogurt with 50\% L. plantrium added to 50\% yogurt culture (S. thermophilus and L. bulgaricus) [64].

Martinez et al. reported that the probiotics Pediococcus pentosaceus and Kluyveromyces marxianus could adsorb AFM1 in milk and convert it to less toxic metabolites [65].

Zhai et al. revealed that exposure to cadmium, which is frequently taken with drinking water, can be prevented with Lactobacillus strains, and absorption can be prevented by protecting the intestinal barrier [66].

The presence of heavy metals such as chromium, arsenic, cadmium, and lead, which are potential bioaccumulative toxins in dairy products, is a serious health risk. Eggs, which are very beneficial and nutritious, can also contain high levels of heavy metals through contaminated food and water.

Due to their beneficial effect on human health, probiotic bacteria, which include several strains of Lactic acid bacteria, are widely used in the food industry. In a study conducted in 2017, it was stated that the use of E. faecium (E980) may be allowed for the control of serious heavy metals (lead and cadmium) contaminating foodstuffs used in infant feeding.

Clostridium (C.) botulinum is the causative agent of foodborne poisonings such as botulism, which includes high mortality rates in animals and humans. Studies have shown that Pediococcus pentosaceus ATCC 43200, P. pentosaceus ATCC 43201, L. lactic subsp. lactic ATCC 11454, L. acidophilus N2, L. plantarum Lb75, L. plantarum Lb592 and L. plantarum $\mathrm{BN}$ provide bacteriocin-like protection against all C. botulinum strains [67].

\section{Cosmetics and Personal care products}

The skin creates an interaction between microbes and cells. Recent studies point out that there is a link between the microbiota, barrier function and the innate immune system, and that the skin microbiota has a beneficial role. Protection of the microflora is a good manner to preserve healthy skin functions. The aim of modern therapies is the maintenance or restoration of healthy skin microbiota [68].

While the use of probiotics in commercial products continues to increase, many claims about probiotics are based on preliminary evaluations, uncontrolled studies, observations, or more speculation. However, over time, many studies have been conducted on the role of probiotics in the treatment of gastrointestinal (GI) disorders. In addition, the cosmetics industry is conducting research on probiotics to improve the function and beauty of the skin and is evaluating whether or not probiotics can be used for skin treatment.

It has been reported that oral intake of lactobacilli can help manage inflammation, as well as heal burns and scars, rejuvenate skin tissues, protect and heal against ultraviolet rays, and increase the innate immunity of the skin. A study of topically used Streptococcus thermophilus on the forearms has suggested that it improves skin 
hydration, while topically used Lactobacillus plantarum HY7714 has led to a decrease in facial wrinkle depth after 12 weeks $[69,70]$.

Probiotics for oral health predominantly contain the genera Streptococcus and Lactobacillus. Kenneth et al. explained that Lactobacillus, Bacillus, Escherichia, Enterococcus, Streptococcus, Bifidobacterium and /or Saccharomyces can prevent halitosis, gingivitis, and periodontitis.

Using probiotic bacteria to treat vaginal infections has been well-documented by Koenig et al. and Huang, respectively, with their topical probiotic compositions in the forms of lotion, cream, jelly, powder, etc. Generally, Lactobacillus, Saccharomyces, Bifidobacterium, Pediococcus, Leuconostoc, Micrococcus, Escherichia, Staphylococcus, Streptococcus, Candida, and Bacillus are included [71].

\section{Conclusion}

Endocrine disruptors are a class of environmental xenobiotics which have several detrimental effects on host organisms. These effects may result in different serious diseases in organs and systems. Their negative effects on the nervous system, immune system and their teratogenic effects are well-known. These substances have a dual effect on intestinal microorganisms, both affecting the number of microorganisms and disrupting the hormone systems regulated by microorganisms, and disrupting the hormone systems and causing the dysfunction of microorganisms. With more detailed studies to be done, the usage areas of different probiotics will be expanded in order to prevent the negative effects of endocrine-disrupting chemicals. In light of the studies, it is clear that probiotics have a lot of promise in new treatment strategy applications.

\section{References}

1. Ana R, Nicholas O, Serrano FO. Human exposure to endocrine-disrupting chemicals: Assessing the total estrogenic xenobiotic burden. TrAC Trends in Analytical Chemistry. 1997 16:613-619. doi:10.1016/S0165-9936(97)00101-5.

2. Darbre PD. Chemical components of plastics as endocrine disruptors: Overview and commentary. Birth Defects Res. 2020 Oct;112(17):1300-1307. doi: 10.1002/bdr2.1778.

3. Kahn LG, Philippat C, Nakayama SF, Slama R, Trasande L Endocrine-disrupting chemicals: implications for human health. The Lancet Diabetes \& Endocrinology. 2020 8:703-718. doi:10.1016/S2213-8587(20)30129-7.

4. Golub M, Doherty J. Triphenyltin as a potential human endocrine disruptor. J Toxicol Environ Health B Crit Rev. 2004 Jul-Aug;7(4):281-95. doi: 10.1080/10937400490452705.

5. Pironti C, Maria R, Proto A, Bianco PM, Montano L, Motta O. Endocrine-Disrupting Compounds: An Overview on Their Occurrence in the Aquatic Environment and Human Exposure. Water. 2021 May 13: 1347. doi:10.3390/w13101347.

6. Annamalai J, Namasivayam V. Endocrine disrupting chemicals in the atmosphere: Their effects on humans and wildlife. Environ Int. 2015 Mar;76:78-97. doi: 10.1016/j.envint.2014.12.006. 
7. Dziewirska E, Hanke W, Jurewicz J. Environmental non-persistent endocrine-disrupting chemicals exposure and reproductive hormones levels in adult men. Int J Occup Med Environ Health. 2018 Oct 23;31(5):551-573. doi: 10.13075/ijomeh.1896.01183.

8. Garcia-Gonzalez N, Prete R, Perugini M, Merola C, Battista N, Corsetti A. Probiotic antigenotoxic activity as a DNA bioprotective tool: a minireview with focus on endocrine disruptors. FEMS Microbiol Lett. 2020 Feb 1;367(3):fnaa041. doi: 10.1093/femsle/fnaa041.

9. Roman P, Cardona D, Sempere L, Carvajal F. Microbiota and organophosphates. Neurotoxicology. 2019 Dec;75:200-208. doi: 10.1016/j.neuro.2019.09.013.

10. Giommi C, Habibi HR, Candelma M, Carnevali O, Maradonna F. Probiotic Administration Mitigates Bisphenol A Reproductive Toxicity in Zebrafish. Int J Mol Sci. 2021 Aug 27;22(17):9314. doi: 10.3390/ijms22179314.

11. Neuman H, Debelius JW, Knight R, Koren O. Microbial endocrinology: the interplay between the microbiota and the endocrine system. FEMS Microbiol Rev. 2015 Jul;39(4):509-21. doi: 10.1093/femsre/fuu010.

12. Elahi S, Ertelt JM, Kinder JM, Jiang TT, Zhang X, Xin L, Chaturvedi V, Strong BS, Qualls JE, Steinbrecher KA, Kalfa TA, Shaaban AF, Way SS. Immunosuppressive CD71+ erythroid cells compromise neonatal host defence against infection. Nature. 2013 Dec 5;504(7478):158-62. doi: 10.1038/nature12675.

13. Lyte M, Ernst S. Catecholamine induced growth of gram negative bacteria. Life Sci. 1992;50(3):20312. doi: 10.1016/0024-3205(92)90273-r.

14. Abisado RG, Benomar S, Klaus JR, Dandekar AA, Chandler JR. Bacterial Quorum Sensing and Microbial Community Interactions. mBio. 2018 May 22;9(3):e02331-17. doi: 10.1128/mBio.02331-17.

15. Hegde M, Wood TK, Jayaraman A. The neuroendocrine hormone norepinephrine increases Pseudomonas aeruginosa PA14 virulence through the las quorum-sensing pathway. Appl Microbiol Biotechnol. 2009 Sep;84(4):763-76. doi: 10.1007/s00253-009-2045-1.

16. Wichmann A, Allahyar A, Greiner TU, Plovier H, Lundén GÖ, Larsson T, Drucker DJ, Delzenne NM, Cani PD, Bäckhed F. Microbial modulation of energy availability in the colon regulates intestinal transit. Cell Host Microbe. 2013 Nov 13;14(5):582-90. doi: 10.1016/j.chom.2013.09.012.

17. Vandenberghe, Luciana \& Spier, Michele \& Medeiros, Adriane \& Yamaguishi, Caroline \& De Dea Lindner, Juliano \& Pandey, Ashok \& Thomaz-Soccol, Vanete. The Potential of Probiotics: A Review. Food Technology and Biotechnology . 2010 June 48 (4):413-434.

18. Zommiti M, Feuilloley MGJ, Connil N. Update of Probiotics in Human World: A Nonstop Source of Benefactions till the End of Time. Microorganisms. 2020 Nov 30;8(12):1907. doi: 10.3390/microorganisms 8121907 .

19. Hampl R, Stárka L. Endocrine disruptors and gut microbiome interactions. Physiol Res. 2020 Sep 30;69(Suppl 2):S211-S223. doi: 10.33549/physiolres.934513.

20. Knezevic J, Starchl C, Tmava Berisha A, Amrein K. Thyroid-Gut-Axis: How Does the Microbiota Influence Thyroid Function? Nutrients. 2020 Jun 12;12(6):1769. doi: 10.3390/nu12061769.

21. Fröhlich E, Wahl R. Microbiota and Thyroid Interaction in Health and Disease. Trends Endocrinol Metab. 2019 Aug;30(8):479-490. doi: 10.1016/j.tem.2019.05.008. 
22. Talebi S, Karimifar M, Heidari Z, Mohammadi H, Askari G. The effects of synbiotic supplementation on thyroid function and inflammation in hypothyroid patients: A randomized, double-blind, placebo-controlled trial. Complement Ther Med. 2020 Jan;48:102234. doi: 10.1016/j.ctim.2019.102234.

23. Javurek AB, Spollen WG, Johnson SA, Bivens NJ, Bromert KH, Givan SA, Rosenfeld CS. Effects of exposure to bisphenol A and ethinyl estradiol on the gut microbiota of parents and their offspring in a rodent model. Gut Microbes. 2016 Nov;7(6):471-485. doi: 10.1080/19490976.2016.1234657.

24. Lai KP, Chung YT, Li R, Wan HT, Wong CK. Bisphenol A alters gut microbiome: Comparative metagenomics analysis. Environ Pollut. 2016 Nov;218:923-930. doi: 10.1016/j.envpol.2016.08.039.

25. Koestel ZL, Backus RC, Tsuruta K, Spollen WG, Johnson SA, Javurek AB, Ellersieck MR, Wiedmeyer CE, Kannan K, Xue J, Bivens NJ, Givan SA, Rosenfeld CS. Bisphenol A (BPA) in the serum of pet dogs following short-term consumption of canned dog food and potential health consequences of exposure to BPA. Sci Total Environ. 2017 Feb 1;579:1804-1814. doi: 10.1016/j.scitotenv.2016.11.162.

26. Jin Y, Zeng Z, Wu Y, Zhang S, Fu Z. Oral Exposure of Mice to Carbendazim Induces Hepatic Lipid Metabolism Disorder and Gut Microbiota Dysbiosis. Toxicol Sci. 2015 Sep;147(1):116-26. doi: 10.1093/toxsci/kfv115.

27. Roslund MI, Rantala S, Oikarinen S, Puhakka R, Hui N, Parajuli A, Laitinen OH, Hyöty H, Rantalainen AL, Sinkkonen A; ADELE team. Endocrine disruption and commensal bacteria alteration associated with gaseous and soil PAH contamination among daycare children. Environ Int. 2019 Sep;130:104894. doi: 10.1016/j.envint.2019.06.004.

28. Gao B, Bian X, Mahbub R, Lu K. Sex-Specific Effects of Organophosphate Diazinon on the Gut Microbiome and Its Metabolic Functions. Environ Health Perspect. 2017 Feb;125(2):198-206. doi: 10.1289/EHP202.

29. Hu J, Raikhel V, Gopalakrishnan K, Fernandez-Hernandez H, Lambertini L, Manservisi F, Falcioni L, Bua L, Belpoggi F, L Teitelbaum S, Chen J. Effect of postnatal low-dose exposure to environmental chemicals on the gut microbiome in a rodent model. Microbiome. 2016 Jun 14;4(1):26. doi: 10.1186/s40168-016-0173-2.

30. Kan H, Zhao F, Zhang XX, Ren H, Gao S. Correlations of Gut Microbial Community Shift with Hepatic Damage and Growth Inhibition of Carassius auratus Induced by Pentachlorophenol Exposure. Environ Sci Technol. 2015 Oct 6;49(19):11894-902. doi: 10.1021/acs.est.5b02990.

31. Mohammadi M, Shadnoush M, Sohrabvandi S, Yousefi M, Khorshidian N, Mortazavian AM. Probiotics as potential detoxification tools for mitigation of pesticides: a mini review. International Journal of Food Science \& Technology. 2020 Nov:56. doi:10.1111/ijfs.14880.

32. Yuan X, Pan Z, Jin C, Ni Y, Fu Z, Jin Y. Gut microbiota: An underestimated and unintended recipient for pesticide-induced toxicity. Chemosphere. 2019 Jul;227:425-434. doi: 10.1016/j.chemosphere.2019.04.088.

33. Wang Y, Zhu H, Kannan K. A Review of Biomonitoring of Phthalate Exposures. Toxics. 2019 Apr 5;7(2):21. doi: 10.3390/toxics7020021.

34. Posnack NG. The adverse cardiac effects of Di(2-ethylhexyl)phthalate and Bisphenol A. Cardiovasc Toxicol. 2014 Dec;14(4):339-57. doi: 10.1007/s12012-014-9258-y. 
35. Parks LG, Ostby JS, Lambright CR, Abbott BD, Klinefelter GR, Barlow NJ, Gray LE Jr. The plasticizer diethylhexyl phthalate induces malformations by decreasing fetal testosterone synthesis during sexual differentiation in the male rat. Toxicol Sci. 2000 Dec;58(2):339-49. doi: 10.1093/toxsci/58.2.339.

36. Gray LE Jr, Ostby J, Furr J, Price M, Veeramachaneni DN, Parks L. Perinatal exposure to the phthalates DEHP, BBP, and DINP, but not DEP, DMP, or DOTP, alters sexual differentiation of the male rat. Toxicol Sci. 2000 Dec;58(2):350-65. doi: 10.1093/toxsci/58.2.350.

37. Tian X, Yu Z, Feng P, Ye Z, Li R, Liu J, Hu J, Kakade A, Liu P, Li X. Lactobacillus plantarum TW1-1 Alleviates Diethylhexylphthalate-Induced Testicular Damage in Mice by Modulating Gut Microbiota and Decreasing Inflammation. Front Cell Infect Microbiol. 2019 Jun 26;9:221. doi: 10.3389/fcimb.2019.00221.

38. Baralić K, Živančević K, Javorac D, Buha Djordjevic A, Anđelković M, Jorgovanović D, Antonijević Miljaković E, Ćurčić M, Bulat Z, Antonijević B, Đukić-Ćosić D. Multi-strain probiotic ameliorated toxic effects of phthalates and bisphenol A mixture in Wistar rats. Food Chem Toxicol. 2020 Sep;143:111540. doi: 10.1016/j.fct.2020.111540.

39. Tang, Fiona \& Lenzen, Manfred \& McBratney, Alexander \& Maggi, Federico. (2021). Risk of pesticide pollution at the global scale. Nature Geoscience. 14. 1-5. 10.1038/s41561-021-00712-5.

40. Trinder M, McDowell TW, Daisley BA, Ali SN, Leong HS, Sumarah MW, Reid G. Probiotic Lactobacillus rhamnosus Reduces Organophosphate Pesticide Absorption and Toxicity to Drosophila melanogaster. Appl Environ Microbiol. 2016 Sep 30;82(20):6204-6213. doi: 10.1128/AEM.01510-16.

41. Daisley BA, Trinder M, McDowell TW, Collins SL, Sumarah MW, Reid G. Microbiota-Mediated Modulation of Organophosphate Insecticide Toxicity by Species-Dependent Interactions with Lactobacilli in a Drosophila melanogaster Insect Model. Appl Environ Microbiol. 2018 Apr 16;84(9):e02820-17. doi: 10.1128/AEM.02820-17.

42. Harishankar MK, Sasikala C, Ramya M. Efficiency of the intestinal bacteria in the degradation of the toxic pesticide, chlorpyrifos. 3 Biotech. 2013 Apr;3(2):137-142. doi: 10.1007/s13205-012-0078-0.

43. Nowak A, Libudzisz Z. Ability of probiotic Lactobacillus casei DN 114001 to bind or/and metabolise heterocyclic aromatic amines in vitro. Eur J Nutr. 2009 Oct;48(7):419-27. doi: 10.1007/s00394-0090030-1.

44. Oatley JT, Rarick MD, Ji GE, Linz JE. Binding of aflatoxin B1 to bifidobacteria in vitro. J Food Prot. 2000 Aug;63(8):1133-6. doi: 10.4315/0362-028x-63.8.1133.

45. Hernandez-Mendoza A, Guzman-de-Peña D, Garcia HS. Key role of teichoic acids on aflatoxin B binding by probiotic bacteria. J Appl Microbiol. 2009 Aug;107(2):395-403. doi: 10.1111/j.13652672.2009.04217.x.

46. Bagherpour Shamloo H, Golkari S, Faghfoori Z, Movassaghpour A, Lotfi H, Barzegari A, Yari Khosroushahi A. Lactobacillus Casei Decreases Organophosphorus Pesticide Diazinon Cytotoxicity in Human HUVEC Cell Line. Adv Pharm Bull. 2016 Jun;6(2):201-10. doi: 10.15171/apb.2016.028..

47. Lahtinen SJ, Haskard CA, Ouwehand AC, Salminen SJ, Ahokas JT. Binding of aflatoxin B1 to cell wall components of Lactobacillus rhamnosus strain GG. Food Addit Contam. 2004 Feb;21(2):15864. doi: 10.1080/02652030310001639521. 
48. Zhai Q, Wang G, Zhao J, Liu X, Narbad A, Chen YQ, Zhang H, Tian F, Chen W. Protective effects of Lactobacillus plantarum CCFM8610 against chronic cadmium toxicity in mice indicate routes of protection besides intestinal sequestration. Appl Environ Microbiol. 2014 Jul;80(13):4063-71. doi: 10.1128/AEM.00762-14.

49. Kamaladevi A, Ganguli A, Balamurugan K. Lactobacillus casei stimulates phase-II detoxification system and rescues malathion-induced physiological impairments in Caenorhabditis elegans. Comp Biochem Physiol C Toxicol Pharmacol. 2016 Jan;179:19-28. doi: 10.1016/j.cbpc.2015.08.004.

50. Wu G, Xiao X, Feng P, Xie F, Yu Z, Yuan W, Liu P, Li X. Gut remediation: a potential approach to reducing chromium accumulation using Lactobacillus plantarum TW1-1. Sci Rep. 2017 Nov 8;7(1):15000. doi: 10.1038/s41598-017-15216-9.

51. Bouhafs L, Moudilou EN, Exbrayat JM, Lahouel M, Idoui T. Protective effects of probiotic Lactobacillus plantarum BJ0021 on liver and kidney oxidative stress and apoptosis induced by endosulfan in pregnant rats. Ren Fail. 2015;37(8):1370-8. doi: 10.3109/0886022X.2015.1073543.

52. Villarini M, Caldini G, Moretti M, Trotta F, Pasquini R, Cenci G. Modulatory activity of a Lactobacillus casei strain on 1,2-dimethylhydrazine-induced genotoxicity in rats. Environ Mol Mutagen. 2008 Apr;49(3):192-9. doi: 10.1002/em.20367.

53. Anderson RC, Cookson AL, McNabb WC, Park Z, McCann MJ, Kelly WJ, Roy NC. Lactobacillus plantarum MB452 enhances the function of the intestinal barrier by increasing the expression levels of genes involved in tight junction formation. BMC Microbiol. 2010 Dec 9;10:316. doi: 10.1186/1471-2180-10-316.

54. Daisley BA, Trinder M, McDowell TW, Welle H, Dube JS, Ali SN, Leong HS, Sumarah MW, Reid G. Neonicotinoid-induced pathogen susceptibility is mitigated by Lactobacillus plantarum immune stimulation in a Drosophila melanogaster model. Sci Rep. 2017 Jun 2;7(1):2703. doi: 10.1038/s41598-017-02806-w.

55. Trinder M, McDowell TW, Daisley BA, Ali SN, Leong HS, Sumarah MW, Reid G. Probiotic Lactobacillus rhamnosus Reduces Organophosphate Pesticide Absorption and Toxicity to Drosophila melanogaster. Appl Environ Microbiol. 2016 Sep 30;82(20):6204-6213. doi: 10.1128/AEM.01510-16.

56. Bagherpour Shamloo H, Golkari S, Faghfoori Z, Movassaghpour A, Lotfi H, Barzegari A, Yari Khosroushahi A. Lactobacillus Casei Decreases Organophosphorus Pesticide Diazinon Cytotoxicity in Human HUVEC Cell Line. Adv Pharm Bull. 2016 Jun;6(2):201-10. doi: 10.15171/apb.2016.028.

57. Cardona D, López-Granero C, Cañadas F, Llorens J, Flores P, Pancetti F, Sánchez-Santed F. Dosedependent regional brain acetylcholinesterase and acylpeptide hydrolase inhibition without cell death after chlorpyrifos administration. J Toxicol Sci. 2013;38(2):193-203. doi: 10.2131/jts.38.193.

58. Cardona F, Andrés-Lacueva C, Tulipani S, Tinahones FJ, Queipo-Ortuño MI. Benefits of polyphenols on gut microbiota and implications in human health. J Nutr Biochem. 2013 Aug;24(8):1415-22. doi: 10.1016/j.jnutbio.2013.05.001.

59. Jafari M, Salehi M, Ahmadi S, Asgari A, Abasnezhad M, Hajigholamali M. The role of oxidative stress in diazinon-induced tissues toxicity in Wistar and Norway rats. Toxicol Mech Methods. 2012 Oct;22(8):638-47. doi: 10.3109/15376516.2012.716090. 
60. Abdel-Daim MM. Synergistic protective role of ceftriaxone and ascorbic acid against subacute diazinon-induced nephrotoxicity in rats. Cytotechnology. 2016 Mar;68(2):279-89. doi: 10.1007/s10616-014-9779-z.

61. Verma A, Shukla G. Synbiotic (Lactobacillus rhamnosus+Lactobacillus acidophilus+inulin) attenuates oxidative stress and colonic damage in 1,2 dimethylhydrazine dihydrochloride-induced colon carcinogenesis in Sprague-Dawley rats: a long-term study. Eur J Cancer Prev. 2014 Nov;23(6):550-9. doi: 10.1097/CEJ.0000000000000054.

62. Barman DN, Haque MA, Islam SM, Yun HD, Kim MK. Cloning and expression of ophB gene encoding organophosphorus hydrolase from endophytic Pseudomonas sp. BF1-3 degrades organophosphorus pesticide chlorpyrifos. Ecotoxicol Environ Saf. 2014 Oct;108:135-41. doi: 10.1016/j.ecoenv.2014.06.023.

63. Tang FL, Manfred L, McBratney A, Maggi F. Risk of pesticide pollution at the global scale. Nature Geoscience. 2021 March 14:1-5. doi:10.1038/s41561-021-00712-5.

64. Elsanhoty R, Salam S, Ramadan M, Badr FH. Detoxification of aflatoxin M1 in yoghurt using probiotics and lactic acid bacteria. Food Control. 2014 March 43:129-134.doi: 10.1016/j.foodcont.2014.03.002.

65. Martínez MP, Magnoli AP, González Pereyra ML, Cavaglieri L. Probiotic bacteria and yeasts adsorb aflatoxin M1 in milk and degrade it to less toxic AFM1-metabolites. Toxicon. 2019 Oct 25;172:1-7. doi: 10.1016/j.toxicon.2019.10.001.

66. Zhai Q, Tian F, Zhao J, Zhang H, Narbad A, Chen W. Oral Administration of Probiotics Inhibits Absorption of the Heavy Metal Cadmium by Protecting the Intestinal Barrier. Appl Environ Microbiol. 2016 Jun 30;82(14):4429-40. doi: 10.1128/AEM.00695-16.

67. Alizadeh AM, Hashempour F, Alizadeh-Sani M, Maleki M, Azizi-Lalabad M, Khosravi-Darani K. Inhibition of Clostridium botulinum and its toxins by probiotic bacteria and their metabolites: An update review. Quality Assurance and Safety of Crops \& Foods. 2020 12:59-68. doi:10.15586/qas.v12iSP1.823.

68. Krutmann J. Pre- and probiotics for human skin. J Dermatol Sci. 2009 Apr;54(1):1-5. doi: 10.1016/j.jdermsci.2009.01.002.

69. Di Marzio L, Cinque B, Cupelli F, De Simone C, Cifone MG, Giuliani M. Increase of skin-ceramide levels in aged subjects following a short-term topical application of bacterial sphingomyelinase from Streptococcus thermophilus. Int J Immunopathol Pharmacol. 2008 Jan-Mar;21(1):137-43. doi: $10.1177 / 039463200802100115$.

70. Lee DE, Huh CS, Ra J, Choi ID, Jeong JW, Kim SH, Ryu JH, Seo YK, Koh JS, Lee JH, Sim JH, Ahn YT. Clinical Evidence of Effects of Lactobacillus plantarum HY7714 on Skin Aging: A Randomized, Double Blind, Placebo-Controlled Study. J Microbiol Biotechnol. 2015 Dec 28;25(12):2160-8. doi: 10.4014/jmb.1509.09021.

71. Dixit Y, Wagle A, Vakil B. Patents in the Field of Probiotics, Prebiotics, Synbiotics: A Review. Journal of Food: Microbiology, Safety \& Hygiene. 2016 01(02). doi:10.4172/2476-2059.1000111. 


\title{
Mogu li probiotici da dobiju bitku protiv endokrinih ometača iz životne sredine?
}

\author{
Çiğdem Sevim ${ }^{*}$, Mehtap Kara ${ }^{2}$ \\ ${ }^{1}$ University of Kastamonu - Faculty of Medicine, Deparment of Medical Pharmacology, \\ 37200, Kastamonu, Turkey \\ ${ }^{2}$ University of Istanbul - Faculty of Pharmacy, Deparment of Pharmaceutical \\ Toxicology, 34116, Istanbul, Turkey
}

*Autor za korespondenciju: Cigdem Sevim, e-mail: cigdemsevim@kastamonu.edu.tr

\section{Kratak sadržaj}

Jedinjenja koja imaju štetno dejstvo na endokrini sistem nazivaju se endokrinim ometačima (EDCs). Postoji nekoliko vrsta jedinjenja, koji različitim putevima dospevaju u životnu sredinu, a koja se mogu svrstati u grupu endokrinih ometača. Ove hemikalije dovode do širokog opsega efekata štetnih po zdravlje živih bića, u zavisnosti od hormonskog sistema na koji deluju. Ispitivanja u oblasti endokrinih ometača izuzetno su aktuelna, budući da su u širokoj upotrebi i da su živa bića često izložena ovim hemikalijama. Do izlaganja endokrinim ometačima može doći na različite načine, npr. oralnim putem, udisanjem ili preko kože. Parabeni, fenolna jedinjenja, ftalati i pesticidi su najčešći endokrini ometači. Takođe, danas pažnju sve više privlače crevni mikroorganizmi, probiotici i dodaci ishrani koji regulišu ove mikroorganizme i njihovi zaštitni efekti protiv različitih štetnih hemikalija. Iz ovog razloga je sprovedeno mnoštvo studija u ovoj oblasti i date smernice u skladu sa rezultatima tih studija. Pokazano je da probiotici mogu biti opcija za ublažavanje i eliminaciju negativnih posledica štetnih hemikalija, kao i za obezbeđivanje snažne reakcije organizma u uslovima izloženosti. U ovom preglednom radu fokusiraćemo se na endokrine ometače, njihove posledice po zdravlje i na pozitivne efekte probiotika u uslovima izloženosti ovim hemikalijama.

Ključne reči: endokrini ometači, pesticidi, ftalati, probiotici 